\title{
School Personnel Tobacco use in Iran: Results of the Global School
} Personnel Survey

\author{
Farshad AA ${ }^{1}$, Vesali $\mathrm{S}^{2}$, Azaripour $\mathrm{H}^{3}$, Rahimi $\mathrm{Z}^{2}$, Akbari $\mathrm{F}^{4}$ and Asadi-Lari $\mathbf{M}^{5,6 *}$ \\ ${ }^{1}$ Department of Occupational Health, School of Public Health. Tehran University of Medical Sciences, Tehran, Iran \\ ${ }^{2}$ School of Public Health, Tehran University of Medical Sciences, Tehran, Iran \\ ${ }^{3}$ National Committee on Tobacco Control, Ministry of Health and Medical Education, Tehran, Iran \\ ${ }^{4}$ Department of Epidemiology, Tehran University of Medical Sciences, Tehran, Iran \\ ${ }^{5}$ Department of Epidemiology, School of Public Health, Tehran University of Medical Sciences, Iran \\ ${ }^{6}$ Oncopathology Research Centre, Tehran University of Medical Sciences, Tehran, Iran
}

\begin{abstract}
Background: This report features a cross-province comparison of school personnel regarding tobacco use patterns, knowledge of and attitudes toward tobacco, availability of tobacco control teaching materials and training, and school anti-tobacco policies.

Methods: The GSPS is a survey of teaching and non-teaching staff working in schools selected to participate in the Global Youth Tobacco Survey (GYTS). The questionnaire used for GSPS was a common tool standardized for this purpose by the CDC and WHO, consisting 42 questions about demographics ( 5 items), tobacco consumption (9 items), knowledge and attitude (14 items), school policies (4 items), and education programs and curriculum (10 items). All data were analysed using SPSS v.19 to demonstrate frequencies, cross-tabulation with confidence intervals Obtained from chi-square tests and t test. Univariate analysis and odds ratio were used to investigate the strength of association between selected variables. Significance level of 0.05 was considered for statistical analysis.
\end{abstract}

Results: A total of 1005 school personnel (60.5\% teacher) from 196 schools spreading in 27 out of 30 provinces were involved in the survey and returned the completed questionnaires. The overall smoking rate among school personnel was $24 \%, 100$ cigarette smoking $13 \%$ and daily smoking was $7.8 \%$. Nearly all school personnel strongly agreed that schools should have a clear policy for smoking cessation among students (95.3\%) and school personnel (91.8\%). Also about $78.4 \%$ reported that school personnel should be trained specially for smoke cessation.

Conclusion: This study underscores the importance of support for tobacco use prevention in developing countries such as Iran, where tobacco use threatens to contribute to a growing proportion of the burden of disease worldwide. It is important to consider within country variations in tobacco use practices, social norms about smoking, and the available resource infrastructure supporting tobacco use prevention within schools, including comparisons by state, type of school (e.g., government versus private), and rural versus urban.

Keywords: School personnel; Smoking; Tobacco use; Adolescents

\section{Introduction}

Recent reports from the World Health Organisation indicate that only $5 \%$ of the global population is protected by comprehensive national smoke-free legislations and $40 \%$ of countries still allow smoking in public places such as hospitals and schools [1]. In the $20^{\text {th }}$ century the tobacco epidemic killed 100 million people worldwide and it is estimated to cause one billion during the $21^{\text {st }}$ century. Of more than 1 billion smokers alive today, around 500 million will be killed by tobacco [1]. By 2030, about $70 \%$ of deaths attributed to tobacco use will occur in low- and middle-income countries [2]. Children and young people in middle- and low-income countries take up smoking between 5-7 times per day more than high-income countries [3].

Tobacco consumption is the most preventable risk factor of chronic diseases. To support prevention, the WHO Framework Convention on Tobacco Control (FCTC), as a primary prevention approach at its best, was developed [4], which by 2012 has been signed by 168 countries out of 192 WHO member states. This is now one of the most widely supported treaties in the history of the United Nations. Iran was one of the foremost countries that signed the treaty in June 2003.

The core parts of WHO FCTC emphasises at protection from exposure to tobacco smoke, regulations of the content of tobacco products and their disclosure, packaging and labelling, prohibition of tobacco advertising and promotion, public awareness about hazards of tobacco consumption and demand reduction measures, which are highlighted in Articles 6-14. Also illicit trade, supporting alternative activities and worth mentioning, prohibition of tobacco sales to minors, are underscored in Part IV of the FCTC.

Article-20 of the FCTC, in addition, calls for countries to use consistent methodology to monitor progress in reducing tobacco consumption and exposure to tobacco smoke (Global Tobacco Surveillance System: GTSS) [5,6]. GTSS includes collection of data through three surveys: Global Youth Tobacco Survey (GYTS) for youth, Global School Personnel Survey (GSPS) and Global Health Professional Survey (GHPS) for adults [5]. GSPS gathered data from more than 72 countries between 2000 and 2006 [6,7].

Teachers and school personnel have a central role in shaping students' behaviour towards smoking; their daily interactions and strong influence on students make them potentially an influential group for tobacco control $[8,9]$. However, controversial reports exist in the literature, in one hand most of the literature body confirms that

${ }^{*}$ Corresponding author: Asadi-Lari M, Department of Epidemiology and Oncopathology Research Centre, Tehran University of Medical Sciences, Tehran, Iran, E-mail: mohsen.asadi@yahoo.com

Received May 19, 2012; Accepted July 24, 2012; Published July 26, 2012

Citation: Farshad AA, Vesali S, Azaripour H, Rahimi Z, Akbari F, et al. (2012) School Personnel Tobacco use in Iran: Results of the Global School Personnel Survey. Primary Health Care 2:119. doi:10.4172/2167-1079.1000119

Copyright: (c) 2012 Farshad AA. This is an open-access article distributed unde the terms of the Creative Commons Attribution License, which permits unrestricted use, distribution, and reproduction in any medium, provided the original author and source are credited. 
smoking school personnel may have a negative influence on junior high school pupils [10], while in some cultures it is vice versa. This has been shown that particularly ex-smoker teachers have the most positive role in preventing smoking among students while current smokers have the least [11]. Teachers may better predict students' subsequent smoking [12], teachers' knowledge, attitudes and behaviour towards smoking education are closely related to their smoking behaviour, therefore pre- and in-service training in this respect are extremely emphasised $[10,11]$.

School smoking cessation policies, on the other hand, is an effective factor which potentially has major implication on smoking prevention among students [13]. A large study in 12 universities and colleges in the United States revealed that the individual programs, only having a preventive education programs on campus was associated with lower odds of smoking. The existence of smoking cessation programs and designated smoking areas were associated with higher odds of smoking and policies governing the sale and distribution of cigarettes were insignificantly associated with smoking [14]. These facts underpin the importance of implementing or expanding tobacco prevention and education programs to further reduce student smoking rates rather than focusing on policies restricting cigarette sales and use.

This report presents data from the Global School Personnel Survey (GSPS), conducted in 27 out of 30 provinces in Iran, which features a cross-province comparison of school personnel regarding tobacco use patterns, knowledge of and attitudes toward tobacco, availability of tobacco control teaching materials and training, and school antitobacco policies.

\section{Method}

The GSPS was designed to collect information on tobacco use, knowledge and attitudes of school personnel toward tobacco, existence and effectiveness of tobacco control policies in schools, and training and materials available for implementing tobacco prevention, and anti tobacco interventions.

\section{Sample}

The GSPS is a survey of teaching and non-teaching staff working in schools selected to participate in the Global Youth Tobacco Survey (GYTS) [15] . The GYTS used a two-stage cluster sample design to select a representative sample of students $(n=4966$ students aged 1315). Stage 1 consisted of selection of schools, proportional to school enrolment size and in the second stage a random sample of classes within each school was selected. According to the structured global design, all personnel working in the selected schools were eligible, thus invited, to participate in the GSPS [6].

\section{Data collection}

The questionnaire used for GSPS was a common tool standardized for this purpose by the CDC and WHO, consisting 42 questions about demographics (5 items), tobacco consumption (9 items), knowledge and attitude (14 items), school policies (4 items), and education programs and curriculum (10 items). The questionnaire passed standard translation pathway which included forward (English to Farsi) and backward translation, then piloted to all staff of a school to investigate the understandability of the tool; all the process was reported to CDC to obtain final approval.

The GSPS used self-administered, anonymous data-collection procedures. Names of personnel were not collected and participation was voluntary after obtaining formal consent. Trained survey personnel conducted survey. The questionnaire was designed with no skip patterns to allow all respondents to answer all questions. Surveys were completed at schools, generally at staff meetings or after school.

\section{Measures}

This report presents measures of tobacco use prevalence (lifetime cigarette smoking, current cigarette smoking, current use of tobacco products other than cigarettes, and current use of any tobacco products), and the proportion of school staff who ever smoked on school property. Also the existence of school policies for prohibition of tobacco use (among students and school personnel), the proportion of implementing such policies, and components of tobacco-related curriculum (percentage of school personnel who had taught students how to avoid tobacco use, had access to teaching and learning materials about tobacco, had received training to prevent youth tobacco use, or had non-classroom programmes to teach about tobacco prevention among students), and attitudes among school personnel regarding several tobacco issues (concern about tobacco use among youth, teachers as role models, and specific training for school personnel).

\section{Data analysis}

All data were analysed using SPSS $v .19$ to demonstrate frequencies, cross-tabulation with confidence intervals obtained from chi-square tests and t test. Univariate analysis and odds ratio were used to investigate the strength of association between selected variables. Significance level of 0.05 was considered for statistical analysis.

\section{Results}

A total of 1005 school personnel (60.5\% teacher) from 196 schools spreading in 27 out of 30 provinces were involved in the survey and returned the completed questionnaires. Also $43.7 \%$ female, $47.4 \%$ in the age group 30 to 39 years and the highest amount of involvement in health education were $43.1 \%$. The overall smoking rate among school personnel was $24 \%$, the rate of lifetime 100 cigarette smoking was $13 \%$ and daily smoking was $7.8 \%$. In addition, $97.5 \%$ of school personnel had no experience of other forms of tobacco use (chewing tobacco, pipe or Cigar) while only $11.5 \%$ of smokers received recommendation to quit smoking; women prevailed in all smoking rates. The highest percentages of smokers in the age group 50-59 were located. There are significant difference between age groups with ever smoker, 100 cigarette smoking and smoking frequency $(\mathrm{p}<0.001)$ were discussed in Table 1.

The highest prevalence rate of 'ever smoking' was in Tehran (capital) and Ardebil (North West) by 12\%, followed by $8.4 \%$ in Isfahan (Central) and then $6.3 \%$ in Kermanshah (West). The least frequent provinces were as follows: 'Charmahal' and 'Kohgiluyeh' had zero percentage followed by 'Yazd' and 'Kerman' with just one smoker (0.4\%), all in central Iran.

\section{Knowledge and attitudes towards tobacco}

More than eighty percent of school personnel reported to be very concerned about youth tobacco use, which was significantly different between ever smokers and never smokers $(\mathrm{p}<0.001)$ (Table 2$)$. Daily smokers, however, were not different from non-smokers in their concern over youth smoking, in contrast pipe and other forms of smokers were different in this concern $(\mathrm{p}<0.001)$. There was no significant gender difference in their concern over youth smoking. Around $80 \%$ stated that smoking would result in physical addiction and over $90 \%$ believed that school personnel should be a good example of non-smoking for students and tobacco use by school personnel influences youth tobacco 
Citation: Farshad AA, Vesali S, Azaripour H, Rahimi Z, Akbari F, et al. (2012) School Personnel Tobacco use in Iran: Results of the Global School Personnel Survey. Primary Health Care 2:119. doi:10.4172/2167-1079.1000119

Page 3 of 5

\begin{tabular}{|c|c|c|c|c|c|c|c|c|c|c|}
\hline \multirow[t]{3}{*}{ Variable } & & \multicolumn{4}{|l|}{ Gender } & & \multicolumn{4}{|l|}{ Age } \\
\hline & & \multirow{2}{*}{$\begin{array}{l}\text { Female } \\
(\%)\end{array}$} & \multirow{2}{*}{$\begin{array}{l}\text { Male } \\
(\%)\end{array}$} & \multirow[t]{2}{*}{ P-Value } & \multirow[t]{2}{*}{$\mathrm{Cl} 95 \%$} & \multicolumn{4}{|c|}{ Age groups (\%) } & \multirow{2}{*}{$\begin{array}{l}\text { P-Value } \\
0.001\end{array}$} \\
\hline & & & & & & $20-29$ & 30-39 & $40-49$ & $50-59$ & \\
\hline \multirow[t]{2}{*}{ Ever smoked } & Yes & 36.8 & 13.6 & \multirow[t]{2}{*}{0.001} & \multirow[t]{2}{*}{$0.197-0.367$} & 16.8 & 21.8 & 33.1 & 43.3 & \\
\hline & No & 63.2 & 86.4 & & & 83.2 & 78.2 & 66.9 & 56.7 & \\
\hline \multirow[t]{2}{*}{ Smoked at least 100 cigarette } & Yes & 21.9 & 6.1 & \multirow[t]{2}{*}{0.001} & \multirow[t]{2}{*}{$0.154-0.353$} & 5.5 & 10.9 & 22.7 & 30 & \multirow[t]{2}{*}{0.001} \\
\hline & No & 78.1 & 93.9 & & & 94.5 & 89.1 & 77.3 & 70 & \\
\hline \multirow[t]{3}{*}{ Smoking frequency } & Daily & 9.4 & 2.5 & \multirow[t]{3}{*}{0.001} & \multirow{3}{*}{ * } & 2.7 & 4.3 & 10.6 & 10 & \multirow{3}{*}{0.001} \\
\hline & Some days & 10.6 & 6.1 & & & 9.8 & 6.5 & 10.2 & 13.3 & \\
\hline & Never & 80 & 93.1 & & & 87.5 & 89.2 & 79.2 & 76.7 & \\
\hline \multirow{2}{*}{$\begin{array}{l}\text { Ever smoked pipe, chewing, } \\
\text { tobacco, cigar }\end{array}$} & Yes & 3.2 & 2 & \multirow[t]{2}{*}{0.211} & \multirow[t]{2}{*}{$0.271-1.342$} & 4.9 & 1.9 & 2.4 & 3.3 & \multirow[t]{2}{*}{0.261} \\
\hline & No & 96.8 & 98 & & & 95.1 & 98.1 & 97.6 & 96.7 & \\
\hline \multirow{2}{*}{$\begin{array}{l}\text { Ever smoked } 100 \text { times pipe, } \\
\text { chewing, tobacco or cigar }\end{array}$} & Yes & 2.3 & 1.2 & \multirow[t]{2}{*}{0.204} & \multirow[t]{2}{*}{$0.203-1.423$} & 1.1 & 1.9 & 2 & 3.6 & \multirow[t]{2}{*}{0.806} \\
\hline & No & 97.7 & 98.8 & & & 98.9 & 98.1 & 98 & 96.4 & \\
\hline \multirow{3}{*}{$\begin{array}{l}\text { pipe, chewing, tobacco or cigar } \\
\text { smoking frequency }\end{array}$} & Daily & 2.1 & 1.3 & \multirow[t]{3}{*}{0.592} & \multirow[t]{3}{*}{ * } & 1.6 & 1.5 & 1.6 & 3.4 & \multirow[t]{3}{*}{0.971} \\
\hline & Some days & 3.7 & 3.6 & & & 2.2 & 3.4 & 4.1 & 6.9 & \\
\hline & Never & 94.2 & 95.1 & & & 96.2 & 95.1 & 94.3 & 89.7 & \\
\hline \multirow[t]{3}{*}{ Recommended to quit smoking } & Never smoked & 61.6 & 75.1 & \multirow[t]{3}{*}{0.001} & & 77.6 & 69.9 & 61.1 & 63.3 & \\
\hline & Yes & 19.1 & 5.6 & & * & 6.6 & 11 & 16 & 26.7 & 0.001 \\
\hline & No & 19.3 & 19.3 & & & 15.8 & 19.1 & 23 & 10 & \\
\hline
\end{tabular}

*Risk Estimate statistics cannot be computed. They are only computed for a $2 * 2$ table without empty cells.

Table 1: Tobacco consumption.

\begin{tabular}{|c|c|c|c|c|c|c|c|c|}
\hline \multicolumn{2}{|l|}{ VARIABLE } & \multirow{2}{*}{$\begin{array}{l}\text { Percent } \\
83.8 \\
\end{array}$} & \multicolumn{3}{|l|}{ GENDER } & \multicolumn{3}{|c|}{ SMOKING } \\
\hline \multirow[t]{3}{*}{ The amount of worrying about youth smoking } & Very much & & 83.1 & 84.4 & \multirow[t]{3}{*}{0.531} & 73.8 & 85.4 & \multirow[t]{3}{*}{0.002} \\
\hline & Some how & 13.3 & 14.4 & 12.3 & & 23 & 11.8 & \\
\hline & Not at all & 2.9 & 2.5 & 3.2 & & 3.2 & 2.8 & \\
\hline \multirow{3}{*}{$\begin{array}{l}\text { School personnel should be a good example of non- } \\
\text { smoking for students }\end{array}$} & Agree & 97.3 & 98.4 & 96.5 & \multirow[t]{3}{*}{0.020} & 94.5 & 97.8 & \multirow[t]{3}{*}{0.001} \\
\hline & Null & 0.6 & 0.5 & 0.7 & & 2.3 & 4 & \\
\hline & Disagree & 2.1 & 1.1 & 2.9 & & 3.1 & 1.9 & \\
\hline \multirow{3}{*}{$\begin{array}{l}\text { Smoker school personnel recommendation are inef- } \\
\text { fective }\end{array}$} & Agree & 93 & 91.5 & 94.3 & \multirow[t]{3}{*}{0.144} & 89.9 & 93.5 & \multirow[t]{3}{*}{0.001} \\
\hline & Null & 2.6 & 3 & 2.3 & & 2.3 & 2.6 & \\
\hline & Disagree & 4.3 & 5.5 & 3.4 & & 7.8 & 3.9 & \\
\hline \multirow{3}{*}{$\begin{array}{l}\text { There should a clearly policy for smoking cessation } \\
\text { among students }\end{array}$} & Agree & 95.4 & 93.1 & 97.3 & \multirow[t]{3}{*}{0.026} & 89.9 & 96.5 & \multirow[t]{3}{*}{0.013} \\
\hline & Null & 2.3 & 3.2 & 1.6 & & 4.7 & 2 & \\
\hline & Disagree & 2.2 & 3.7 & 1.1 & & 5.4 & 1.5 & \\
\hline \multirow{3}{*}{$\begin{array}{l}\text { There should a clearly policy for smoking cessation } \\
\text { among school personnel }\end{array}$} & Agree & 91.8 & 88.3 & 94.6 & \multirow[t]{3}{*}{0.001} & 83.5 & 93.3 & \multirow[t]{3}{*}{0.001} \\
\hline & Null & 4.4 & 4.8 & 4.1 & & 8.7 & 3.9 & \\
\hline & Disagree & 3.7 & 6.8 & 1.3 & & 7.9 & 2.8 & \\
\hline
\end{tabular}

Table 2: Knowledge and attitude towards tobacco.

use. Meanwhile more than $90 \%$ of respondents assumed that smoker school personnel's recommendations were ineffective. Also about $78.4 \%$ reported that school personnel should be trained specially for smoke cessation (Table 2).

\section{School policies and education programs}

Nearly all school personnel strongly agreed that schools should have a clear policy for smoking cessation among students (95.4\%) and school personnel (91.8\%). Table 3 explains the school policies and teaching programmes from school personnel viewpoints. Almost two thirds of all respondents believed that there were no clear policies to prohibit either students or teachers for smoking in the school, no smoke free policy in school and also the smoke free policy was not implemented. This was significantly different among ever smokers, where two thirds of non-smokers believed that there was no clear policy for prohibition of student smoking, where just half of smokers believed so.

\section{Discussion}

The overall smoking rate among school personnel was 24\%, which was prevailed in females. This rate is remarkably more than the average rate which was reported in the global report of GSPS (1519\%) [6]. Almost all respondents were in support of clear policies for smoking cessation among staff and students, although less than a third of schools had such policies implemented. School personnel can play an important role in tobacco control because of their status as role models in their communities and frequent contact with children. This potential can be limited if school personnel use tobacco, especially in the presence of students on school property [5].

Despite concerns about smoking in young people, especially students, lack of clear policies to cease smoking in schools is alarming; smoking prohibition policies was existed in around one third of schools, $35.2 \%$ for students and $30.2 \%$ for school personnel, which are very far from WHO statistics published during 2000 - 2008 (77\% and 56\%), [6] and a warning point for health policy makers. To resolve this, raising 


\begin{tabular}{|c|c|c|c|c|}
\hline & Variable & & Percent & $95 \% \mathrm{Cli}$ \\
\hline \multirow[t]{5}{*}{ School policies } & \multicolumn{2}{|c|}{$\begin{array}{l}\text { Clear policy for smoking cessation among } \\
\text { students }\end{array}$} & 35.2 & $32.2-38.1$ \\
\hline & \multicolumn{2}{|c|}{$\begin{array}{l}\text { Clear policy for smoking cessation among } \\
\text { teacher }\end{array}$} & 30.2 & $27.0-33.0$ \\
\hline & \multicolumn{2}{|c|}{ Smoke free policy in the school } & 38 & $34.5-40.7$ \\
\hline & \multirow{2}{*}{$\begin{array}{l}\text { Implementing } \\
\text { smoke free policy in } \\
\text { the school }\end{array}$} & Without policy & 55 & $51.9-58.6$ \\
\hline & & Yes & 31.6 & 28.1-34.4 \\
\hline \multirow{10}{*}{$\begin{array}{l}\text { Education } \\
\text { programs and } \\
\text { curriculum }\end{array}$} & \multicolumn{2}{|c|}{ Teaching short term side- effects } & 34.1 & $31.1-37.4$ \\
\hline & \multicolumn{2}{|c|}{ Teaching long term side effect } & 34.3 & $31.2-37.8$ \\
\hline & \multicolumn{2}{|c|}{$\begin{array}{l}\text { Teaching students about the number of } \\
\text { young smokers in the country }\end{array}$} & 18.4 & $15.8-20.9$ \\
\hline & \multicolumn{2}{|c|}{$\begin{array}{l}\text { Teaching students about socio-cultural } \\
\text { effects of smoking }\end{array}$} & 32.5 & $29.6-36.1$ \\
\hline & \multicolumn{2}{|c|}{$\begin{array}{l}\text { Teaching students about communication } \\
\text { skills for smoking cessation }\end{array}$} & 25.7 & $23.4-29.5$ \\
\hline & \multicolumn{2}{|c|}{$\begin{array}{l}\text { Teaching students about smoking cessa- } \\
\text { tion programmes like smoke free day }\end{array}$} & 11.9 & $9.2-13.5$ \\
\hline & \multicolumn{2}{|c|}{ Teaching students about peer pressure } & 29.4 & $26.1-32.1$ \\
\hline & \multicolumn{2}{|c|}{$\begin{array}{l}\text { Access to reference books/materials about } \\
\text { smoking side effects }\end{array}$} & 27.7 & $24.9-30.7$ \\
\hline & \multicolumn{2}{|c|}{ Ever trained for smoking prevention skills } & 20.5 & $18.0-23.1$ \\
\hline & \multicolumn{2}{|c|}{$\begin{array}{l}\text { Any extra work in your school about smok- } \\
\text { ing prevention of students }\end{array}$} & 15.5 & $12.7-17.5$ \\
\hline
\end{tabular}

Table 3: Frequency percentage of school policies and Education program and curriculum.

public awareness and effective educational programs have particular importance. Also access to appropriate educational materials is an important element of an effective curriculum to prevent and reduce tobacco use among students [5].

In our study, only $27.7 \%$ asserted that access to such resources for knowledge of the effects of cigarette smoking and skills to prevent smoking, which are far behind the global statistics ( $44 \%$ in the study from 2000 to 2008) [6]. Nonetheless, knowledge about these health hazards was not associated with teaching about prevention of tobacco use. While these results suggest the importance of further training of teachers and students about the specific health hazards of tobacco use, it is not likely that training alone would be sufficient to assure that tobacco use prevention is incorporated into school curricula [10].

Tobacco use prevention and reduction among students requires a comprehensive approach involving teachers, administrators, parents, and other influential persons [16-19]. School personnel may even under-estimate the smoking behavior of students, therefore more training may enhance their knowledge towards smoking hazards, better estimation of the problem and planning appropriate interventions to reduce smoking and adopt smoking policies at schools. School personnel who participated in GSPS show general willingness to contribute in this effort. The majority in most sites reported that they think school personnel should set an example for students by not using tobacco. Teachers' ability to convey effective anti-tobacco information to students can be diminished if they have not received training to provide tobacco-related information to students or do not have access to adequate teaching materials to support anti-tobacco curricula [20]. However, similar to other studies, the majority of school personnel strongly demanded for specific training to help students avoid or stop using tobacco $[6,20,21]$.

The findings in this report are subject to at least three limitations. First the GSPS sample design uses schools selected for the GYTS. Thus, GSPS is not an independent sample of schools and is dependent on the success of the GYTS. Fortunately, the GSPS school response rate has been greater than $80 \%$ in all but one GSPS site. Secondly, school personnel participation was voluntary, therefore it may be subject to selection bias. Third, findings are based on self-reports from school personnel who may under- or over-report their behavior and their knowledge of school policies. GSPS does not include independent validation of school policies and enforcement of school tobacco control policies.

From 2000 until 2008 GSPS was conducted in 71 countries, which these results is being addressed in a global policy for tackling this health problem. Considering that the proportion of school students is around $20 \%$ of the whole Iranian population and relatively high rate of smoking and other tobacco products among school personnel, targeting this influential group and setting up comprehensive smoking cessation programs is crucial for health policy makers to enforce appropriate legislations and to implement smoking cessations plans throughout the country. It is important to consider the variations in tobacco use practices and school personnel knowledge within the country. Social norms, available resources and infrastructure supporting tobacco use prevention within schools, including comparisons by provinces, type of school (e.g. government versus private), and rural versus urban [10] and continuous monitoring of school staff behavior and knowledge towards smoking should be taken into account in future studies.

\section{References}

1. World Health Organization, WHO Report on the Global Tobacco Epidemic, The MPOWER package 2008 World Health Organization: Geneva.

2. Jha P, Chaloupka FJ (1999) Curbing the epidemic: governments and the economics of tobacco control. The World Bank. Washington DC 8: 196-201.

3. Gajalakshmi CK, et al. (2000) Global patterns of smoking and smokingattributable mortality, in Tobacco Control in Developing Countries, P. Jha and F.J. Chaloupka, Editors. 2000, Oxford University Press: Cary (NC).

4. World Health Organization, WHO Framework Convention on Tobacco Control. 2003, WHO: Geneva, Switzerland.

5. Global Tobacco Surveillance System Collaborating Group (2005) Globa Tobacco Surveillance System (GTSS): purpose, production, and potential. $J$ Sch Health 75: 15-24.

6. GTSS Collaborative Group (2006)The Global School Personnel Survey: a cross-country overview. Tob control 15: i20-i30.

7. CDC website, Global School Personnel Survey (GSPS) Participating Countries

8. Park HK, Al Agili DE, Bartolucci A (2012) Factors Affecting Tobacco Use Among Middle School Students in Saudi Arabia. Matern Child Health J.

9. Rissel C, McLellan L, Bauman A (2000) Factors associated with delayed tobacco uptake among Vietnamese/Asian and Arabic youth in Sydney, NSW. Aust N Z J Public Health 24: 22-28.

10. Ertas N (2007) Factors associated with stages of cigarette smoking among Turkish youth. Eur J Public Health 17: 155-161.

11. Chen TL, Rakip WR (1975) The effect of the teachers smoking behavior on their involvement in smoking education in the schools. J Sch Health 45: 455-461.

12. Niemelä S, Sourander A, Pilowsky DJ, Susser E, Helenius H, et al. (2009) Childhood antecedents of being a cigarette smoker in early adulthood. The Finnish 'From a Boy to a Man' Study. J Child Psychol Psychiatry 50: 343-351.

13. Adams ML, Jason LA, Pokorny S, Hunt $Y$ (2009) The relationship between school policies and youth tobacco use. J Sch Health 79: 17-23.

14. Borders TF, Xu KT, Bacchi D, Cohen L, SoRelle-Miner D, et al. (2005) College campus smoking policies and programs and students' smoking behaviors. BMC Public Health 5: 74

15. Farshad AA, Azaripour H, Asadi-Lari M (2007) Young Adults Smoking Behaviou in Iran: An Initiation for Health Promotion Activities in IUHPE 2007. Vancouver.

16. Ariza C, Nebot M, Tomás Z, Giménez E, Valmayor S, et al. (2008) Longitudina effects of the european smoking prevention framework approach (ESFA) project in spanish adolescents. Eur J Public Health 18: 491-497. 
Citation: Farshad AA, Vesali S, Azaripour H, Rahimi Z, Akbari F, et al. (2012) School Personnel Tobacco use in Iran: Results of the Global School Personnel Survey. Primary Health Care 2:119. doi:10.4172/2167-1079.1000119

17. Virtanen M, Pietikäinen M, Kivimäki M, Luopa P, Jokela J, et al. (2009) Contribution of parental and school personnel smoking to health risk behaviours among finnish adolescents. BMC Public Health 9: 382.

18. Wakefield M, Chaloupka F (2000) Effectiveness of comprehensive tobacco control programmes in reducing teenage smoking in the USA. Tob Control 9: 177-186.

19. Vartiainen E, Pennanen M, Haukkala A, Dijk F, Lehtovuori R, et al. (2007) The effects of a three-year smoking prevention programme in secondary schools in Helsinki. Eur J Public Health 17: 249-256.

20. Sinha DN, Gupta PC, Warren CW, Asma S (2004) Effect of school policy on tobacco use by school personnel in Bihar, India. J Sch Health 74: 3-5.

21. Sinha DN, Gupta PC, Dobe M, Prasad VM (2007) Tobacco control in schools of India: review from India Global School Personnel Survey 2006. Indian J Public Health 51: 101-106. 